\title{
CELLULAR LOCALIZATION OF THE MOLECULAR FORMS OF ACETYLCHOLINESTERASE IN RAT PHEOCHROMOCYTOMA PC12 CELLS TREATED WITH NERVE GROWTH FACTOR ${ }^{1}$
}

\author{
NIBALDO C. INESTROSA, ${ }^{2}$ C. GARY REINESS, ${ }^{3}$ LOUIS F. REICHARD'T, AND ZACH W. HALL ${ }^{4}$ \\ Division of Neurobiology, Departments of Physiology and of Riochemistry and Biophysics, University of California, San Francisco, \\ California 94143
}

\begin{abstract}
In rat pheochromocytoma (PC12) cells treated with nerve growth factor (NGF), there are several molecular forms of the enzyme acetylcholinesterase (AChE) which sediment on sucrose density gradients at 4 to 6,10 , and $16 \mathrm{~S}$, respectively. We have investigated the cellular localization of these forms in PC12 cells. In order to determine which forms are soluble and which are membrane bound, we extracted PC12 cells in buffers of various ionic strengths and detergent compositions. To distinguish internal from external forms of the enzyme, we examined the effect of di-isopropyl fluorophosphate and BW284c51 dibromide, membrane-permeable and -impermeable inhibitors of $\mathrm{AChE}$, respectively, on AChE forms in intact cells. We also determined the susceptibility of the forms in intact cells to collagenase treatment. Based on these studies, we conclude that the globular $\mathrm{G}_{1}$ and $\mathrm{G}_{2}(4$ to $6 \mathrm{~S})$ forms are internal and consist of both soluble and membrane-associated species. Thirty percent of the $\mathrm{G}_{4}(10 \mathrm{~S})$ form is bound to cytoplasmic membrane structures, while the remainder occurs as an integral component of the plasma membrane. The asymmetric $\mathrm{A}_{12}(16 \mathrm{~S})$ form is also a surface protein but is extracted by high salt without detergent and is released from intact cells by collagenase. This form thus contains a collagenous domain and is located outside of the plasma membrane, where it may be associated with an extracellular matrix.
\end{abstract}

Acetylcholinesterase (AChE) in skeletal muscle occurs in several molecular forms that can be separated by velocity sedimentation (Hall, 1973). Recently, these molecules have been shown to belong to two distinct structural classes: the lighter or globular forms, $\mathrm{G}_{1}, \mathrm{G}_{2}$, and $\mathrm{G}_{4}$ (where the subscript denotes the number of catalytic subunits of each form), and the heavy or asymmetric

\footnotetext{
' We wish to thank Drs. Pamela D. Grorin, Ralph J. Greenspan, and Regis B. Kelly for their comments on the manuscript. This work was supported by grants from the Dysautonomia Foundation, Inc. (C. G. R.), the University of California Cancer Research Coordinating Committee, the Muscular Dystrophy Association, the McKnight Foundation, the Sloan Foundation, and the National Science Foundation (Grant BNS-7723851). Additional funding was provided by a March of Dimes Birth Defects Foundation Basil O'Connor Starter Grant (L. F. R.), National Science Foundation Grant BNS-7720556, National Institutes of Health Program Project Grant NS16033 (Z. W. H.), and postdoctoral fellowships from the Muscular Dystrophy Association (N. C. I.) and the National Institutes of Health (C. G. R.)

${ }^{2}$ On leave from the Laboratory of Neurophysiology, Department of Cell Biology, Catholic University of Chile, P.O. Box 114-D, Santiago, Chile.

${ }^{3}$ Present address: Department of Biology, Pomona College, Claremont, CA 91711.

${ }^{4}$ To whom correspondence should be addressed at Department of Physiology, University of California, San Francisco, Parnassus $\Lambda$ venue, San Francisco, CA 94143.
}

forms, $\mathrm{A}_{12}, \mathrm{~A}_{8}$, and $\mathrm{A}_{4}$ (Bon et al., 1979). By analogy with AChE forms in Electrophorus and Torpedo whose structures have been studied intensively, the asymmetric forms are thought to be composed of tetramers of the globular subunits attached to a long, collagen-like tail (Massoulie, 1980). The asymmetric forms are of particular interest because their presence in muscle appears to be dependent upon innervation (Hall, 1973; Koenig and Vigny, 1978; Weinberg and Hall, 1979; Inestrosa et al., 1979; Rubin et al., 1980). Because some AChE is associated with the basal lamina at the neuromuscular junction (McMahan et al., 1978), it has been suggested that the 16 $\mathrm{S}$ form, which has a long, collagen-like tail, is associated with the collagenous extracellular matrix at the synapse (Massoulie, 1980). Direct support for this hypothesis has not yet been obtained. Forms of AChE similar to those in muscle also have been found in central and peripheral nervous tissue (Rieger et al., 1980a; Gisiger et al., 1976); autonomic ganglia in particular have both globular and asymmetric forms (Gisiger et al., 1976).

When treated with nerve growth factor (NGF), rat PC12 pheochromocytoma cells express several differentiated functions similar to sympathetic neurons. Treated cells extend long neurites (Greene and Tishler, 1976) and undergo changes in electrical properties similar to developing sympathetic neurons (Dichter et al., 1977; O'Lague 
and Huttner, 1980). Another characteristic of these cells when exposed to NGF is the appearance of a form of AChE that sediments at $16 \mathrm{~S}$ in sucrose gradients (Rieger et al., 1980b). We have used this homogeneous, nervelike tissue to study the cellular distribution of the various forms of AChE, especially the asymmetric form. Our results indicate that the globular forms, sedimenting at 4 to 6 and $10 \mathrm{~S}$, are distributed within membranous and cytoplasmic compartments within the cell, including the plasma membrane. The $16 \mathrm{~S}$ asymmetric form of $\mathrm{AChE}$, however, is located extracellularly, where it may be part of an extracellular matrix.

\section{Materials and Methods}

Sources for chemicals were: sucrose (enzyme grade), Schwarz Mann Biochemicals; BW284c51 dibromide, Burroughs Wellcome Co.; di-isopropyl fluorophosphate (DFP), Sigma Chemical Co.; collagenase, form III (chromatographically purified and free of detectable nonspecific proteases), Advanced Biofactures Corp., Lynbrook, NY. All other chemicals were of reagent grade.

PC12 cells were grown in Dulbecco's modified Eagle's medium supplemented with $5 \%$ horse serum, $4 \%$ newborn calf serum, and $1 \%$ fetal calf serum (all oblained from the University of California, San Francisco cell culture facility) in 60-mm plastic tissue culture plates (Falcon) coated with rat tail collagen. Experiments were initiated by the addition of $2.5 \mathrm{~S}$ NGF (prepared by the method of Mobley et al., 1976) to the final concentration indicated (normally $100 \mathrm{ng} / \mathrm{ml}$ ). Medium was changed and fresh NGF was added every $2 \mathrm{~d}$.

Cell extracts. The cells were removed from the dishes

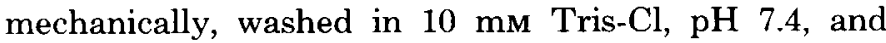
homogenized by hand in a Duall Kontes ground glass homogenizer in $10 \mathrm{~mm}$ Tris- $\mathrm{Cl}, \mathrm{pH} 7.4,1 \mathrm{M} \mathrm{NaCl}, 0.5 \%$ Triton X-100, $20 \mathrm{~mm}$ EDTA (ethylenediaminetetra-acetate), $5 \mathrm{~mm}$ EGTA (ethylene glycol bis( $\beta$-aminoethyl ether)- $N, N, N^{\prime}, N^{\prime}$-tetra-acetic acid), and $20 \mathrm{units} / \mathrm{ml}$ of aprotinin (buffer A).

Velocity sedimentation. The detergent extract thus prepared was centrifuged at $15,000 \times g$ for $15 \mathrm{~min}$ to clear particulate material. Aliquots $(200 \mu \mathrm{l})$ of the resulting supernatants were loaded onto a $5-\mathrm{ml} 5$ to $20 \%$ linear sucrose gradient made up in buffer A. Sedimentation ultracentrifugation was performed in a Beckman L5-65 ultracentrifuge in a SW 50.1 rotor. Samples were centrifuged at $33,000 \mathrm{rpm}$ for $16 \mathrm{hr}$ at $4^{\circ} \mathrm{C}$ and approximately 40 fractions were collected from the bottom of each gradient. The relative proportions of different $\mathrm{AChE}$ molecular forms in relation to total $\mathrm{AChE}$ recovered from the gradient ( $90 \%$ recovery) was evaluated by a graphical integration of the area under each peak and under the total sedimentation profile. Sedimentation coefficients for AChE forms were determined by comparison with those of $\beta$-galactosidase (16 S), catalase $(11.3 \mathrm{~S})$, and alkaline phosphatase (6.4 S). In some experiments, AChE forms were analyzed after centrifugation on linear 5 to $20 \%$ sucrose gradients in a SW 41 Ti rotor. In these cases, the lower molecular weight forms resolved into two peaks of approximately 4 and $6 \mathrm{~S}$ as originally reported by Rieger et al. (1980b) (data not shown). The $6 \mathrm{~S}$ form also can be detected as a shoulder on the $4 \mathrm{~S}$ peak in some gradients (see Fig. $5 c$ ). We thus routinely refer to this activity as the 4 to $6 \mathrm{~S}$ forms.

AChE assay. AChE (EC 3.1.1.7) was assayed by the method of Ellman et al. (1961) using acetylthiocholine as the substrate. Hydrolysis of acetylthiocholine by the samples was reduced at least $95 \%$ by the addition of 5 $\mu \mathrm{M}$ BW284c51 (BW), a selective inhibitor of AChE. Thus, most of the enzymatic activity that we have observed represents specific $\mathrm{AChE}$.

Protection of AChE by BW284c51. PC12 cells treated for $5 \mathrm{~d}$ with $100 \mathrm{ng} / \mathrm{ml}$ of NGF were preincubated for 1 min in the presence of $0.75 \mathrm{~mm}$ BW dissolved in phosphate-buffered saline (PBS) to block the active site of surface AChE. Di-isopropyl fluorophosphate (DFP) then was added in the continued presence of $\mathrm{BW}$ to a final concentration of $2.5 \times 10^{-5} \mathrm{M}$ for $3 \mathrm{~min}$ at room temperature $\left(20^{\circ} \mathrm{C}\right)$. The solution containing DFP was removed, and the cells were washed once with $0.75 \mathrm{~mm}$ BW in PBS and then at least three times with PBS alone. The cells then were extracted and analyzed for AChE forms on sucrose gradients as described above.

Collagenase treatment of PC12 cells. $\mathrm{PC1} 2$ cells were grown for $5 \mathrm{~d}$ in $100 \mathrm{ng} / \mathrm{ml}$ of $2.5 \mathrm{~S} \mathrm{NGF}$, washed to remove serum, and then incubated in the presence of 0.1 $\mathrm{mg} / \mathrm{ml}$ of collagenase, form III, in $20 \mathrm{~mm}$ Tris-Cl, $\mathrm{pH} 7.4$, and $10 \mathrm{mM} \mathrm{CaCl}_{2}$.

Aggregation of $16 \mathrm{~S} \mathrm{AChE}$ in low salt buffer. PC12 cells grown for $5 \mathrm{~d}$ in $100 \mathrm{ng} / \mathrm{ml}$ of NGF were homogenized in buffer $\mathrm{A}$ and centrifuged at $15,000 \times \mathrm{g}$ for 15 min, and the final supernatant was dialyzed overnight at $4^{\circ} \mathrm{C}$ against buffer A without $1 \mathrm{~m} \mathrm{NaCl}$. The low saltsoluble and -insoluble fractions were separated by centrifugation at $15,000 \times g$ for $15 \mathrm{~min}$, and the pellet thus obtained was redissolved in buffer A. Samples of the supernatant and redissolved pellet then were analyzed by velocity sedimentation on linear 5 to $20 \%$ sucrose gradients.

\section{Results}

Regulation of AChE by NGF and induction of the 16 $S$ form. When rat pheochromocytoma PC12 cells are treated with NGF, both the total AChE activity (Rieger et al., 1980b; Lucas et al., 1980) and the activity released into the medium (Lucas et al., 1980) increase, and a new AChE species, the $16 \mathrm{~S}$ form, is induced (Rieger et al., $1980 \mathrm{~b})$. The increase in total AChE activity of PC12 cultures caused by $5 \mathrm{~d}$ of treatment with increasing doses of $2.5 \mathrm{~S} \mathrm{NGF}$ is shown in Figure $1 a$. Total AChE activity increased a maximum of 5 -fold in our culture conditions. Figure $1 b$ shows examples of the distribution in sucrose gradients of AChE forms from PC12 cells treated with various concentrations of NGF. Three clear peaks of AChE activity with apparent sedimentation coefficients of 4,10 , and $16 \mathrm{~S}$ were observed after incubation with $100 \mathrm{ng} / \mathrm{ml}$ of NGF. Each of the peaks represents a stable form of the enzyme since the sedimentation properties were retained after dialysis and resedimentation. This is illustrated for the $16 \mathrm{~S}$ form in Figure $1 c$.

The active site of $16 \mathrm{SAChE}$ is extracellular. To determine which forms of the enzyme are exposed on the cell surface, we examined the effects of enzyme inhibitors differing in lipid solubility and hence in ability to cross 


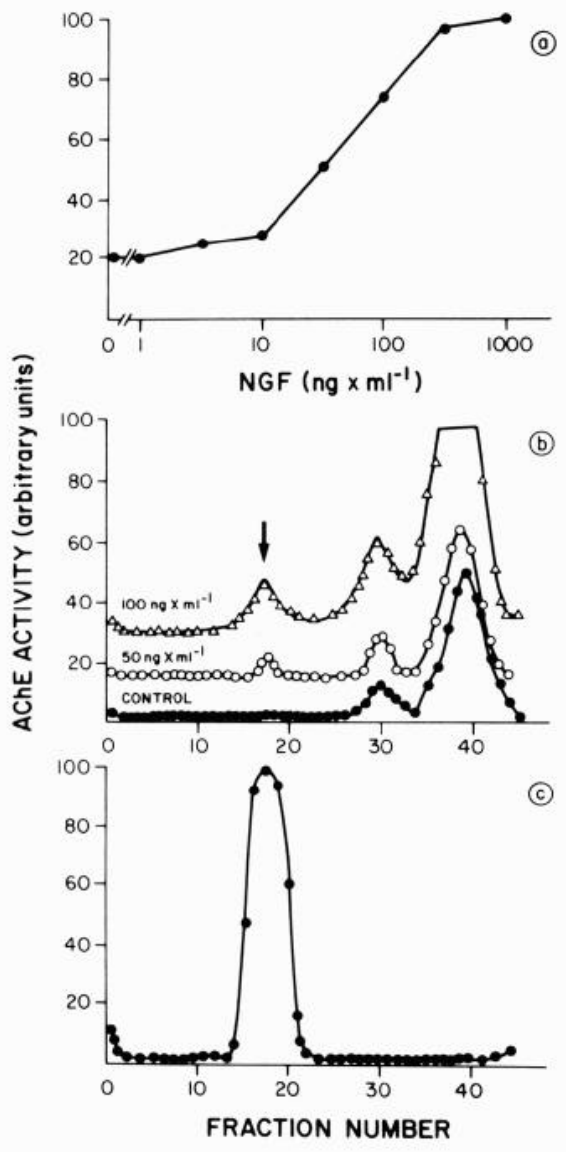

Figure 1. Effects of NGF concentration on total AChE and on different molecular forms. $a$, After 5 days in NGF, the cells were removed from the dishes mechanically, washed in $10 \mathrm{~mm}$ Tris- $\mathrm{Cl}, \mathrm{pH}$ 7.4, and homogenized in buffer A (see "Materials and Methods"). Aliquots then were assayed for AChE activity by the method of Ellman et al. (1961). $b$, Cells were grown, harvested, and extracted as above and the detergent extract was centrifuged at $15,000 \times g$ for $15 \mathrm{~min}$. The resulting supernatant $(0.2 \mathrm{ml})$ was applied to a $5-\mathrm{ml} 5$ to $20 \%$ linear sucrose density gradient made up in buffer A. The figure shows the profile of AChE forms in untreated cells (-) and those that received $50 \mathrm{ng} / \mathrm{ml}(O)$ or $100 \mathrm{ng} / \mathrm{ml}(\triangle)$ of $\mathrm{NGF}$ for $5 \mathrm{~d}$ prior to harvesting. Curves have been displaced along the ordinate for clarity. The arrow corresponds to the marker $\beta$-galactosidase. $c$, Sucrose gradient profile of $16 \mathrm{~S} \mathrm{AChE}$ from $\mathrm{PC} 12$ cells treated with $2.5 \mathrm{~S}$ NGF after recentrifugation. Factors containing $16 \mathrm{~S}$ $\mathrm{AChE}$ from a sucrose gradient run as above $(b)$ were pooled, concentrated, dialyzed against buffer A overnight at $4^{\circ} \mathrm{C}$, and then recentrifuged and analyzed as above. The peak of maximum activity in each figure was assigned a value of 100 and the other points were normalized accordingly.

cell membranes (McIssac and Koelle, 1959; Rieger et al., 1976a; Rotundo and Fambrough, 1980; Taylor et al., 1981). Using combinations of these inhibitors, it is possible to inactivate intracellular AChE irreversibly and then to identify on sucrose gradients the forms that remain active. Intact $\mathrm{PC} 12$ cells were treated with BW284c51 (BW), a water-soluble compound that reversibly blocks the AChE catalytic site and that crosses membranes poorly. With the cells still exposed to BW, the internal AChE was inactivated with an irreversible inhibitor, di-isopropyl fluorophosphate (DFP), which is lipid soluble and easily crosses the cell membrane to inactivate the intracellular AChE permanently. Since the inhibition caused by BW is readily reversible, the protected form could be assayed for activity after sequential removal of the excess DFP and then of the BW. In these experiments, 20 to $25 \%$ of the total cellular AChE was protected by BW. Analysis of the remaining active AChE forms by velocity sedimentation in sucrose gradients (Fig. 2) showed that the $16 \mathrm{~S}$ form was completely (97.3\%) protected, that the $10 \mathrm{~S}$ form was partially $(73 \%)$ protected, and that at least $88 \%$ of the 4 to $6 \mathrm{~S}$ forms was inhibited by this procedure.

These results indicate that all of the $16 \mathrm{~S} \mathrm{AChE}$ form $\left(\mathrm{A}_{12}\right)$ and most $(70 \%)$ of the $10 \mathrm{~S}$ form $\left(\mathrm{G}_{4}\right)$ have the active site exposed to the extracellular fluid, whereas the 4 to $6 \mathrm{~S}$ forms $\left(\mathrm{G}_{1}\right.$ and $\left.\mathrm{G}_{2}\right)$ are localized in an interior compartment of the PC12 cells.

$16 S$ AChE is solubilized by high salt., In order to investigate further the cellular localization of the various forms of $\mathrm{AChE}$, we extracted cells in a variety of buffers designed to solubilize differentially the membrane-bound and soluble forms of the enzyme. The optimum solubilization of AChE was obtained by extraction with $1 \mathrm{M}$ $\mathrm{NaCl}, 20 \mathrm{~mm}$ EDTA, and $0.5 \%$ Triton X-100. Under these conditions, $95 \%$ of the total AChE in the cells is solubilized. Figure $3 a$ shows a sucrose gradient profile of AChE forms in such an extract. Extraction of the cells in low salt buffer (100 mm NaCl and $20 \mathrm{~mm}$ EDTA) solubilized

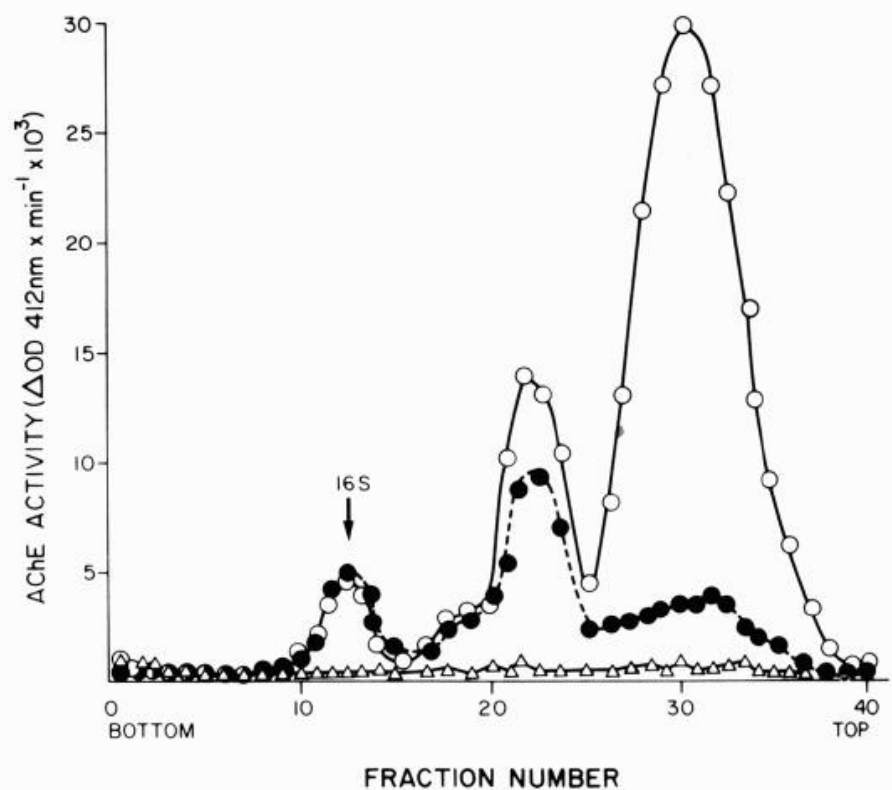

Figure 2. Protection of $16 \mathrm{~S}$ AChE by BW284c51. This sucrose gradient profile of AChE was obtained from $\mathrm{PC} 12$ cells grown for $5 \mathrm{~d}$ in $2.5 \mathrm{~S} \mathrm{NGF}$. The curves represent forms of AChE in control cells $(O)$, in cells in which AChE had been inactivated by DFP $(\triangle)$, and in cells treated for $1 \mathrm{~min}$ in 0.75 mM BW before DFP inactivation as described under "Materials and Methods" (O). Multiplication by 0.0735 converts the results to micromoles of substrate hydrolyzed per min. Pretreatment of the cells with BW for 6 sec gave similar results, while pretreatment for $6 \mathrm{~min}$ resulted in additional protection of 4 to $6(43 \%$ instead of $12 \%)$ and $10 \mathrm{~S}$ forms ( $82 \%$ instead of $73 \%)$, suggesting that the $\mathrm{BW}$ was able to cross the membrane after longer exposure times. 
only $30 \%$ of the total activity; this consisted entirely of the 4 to $6 \mathrm{~S}$ forms when the activity was analyzed in gradients containing Triton X-100 (data not shown). In gradients without detergent, however, $40 \%$ of this activity aggregated into forms of higher sedimentation coefficients, indicating that some of the 4 to $6 \mathrm{~S}$ activity interacts with detergent (Lazar and Vigny, 1980). When NGF-treated PC12 cells were homogenized in $1 \mathrm{M} \mathrm{NaCl}$, $20 \mathrm{~mm}$ EDTA without detergent, all of the $16 \mathrm{~S}$ form and a small fraction of the $10 \mathrm{~S}$ form (13\%) were solubilized in addition to the 4 to $6 \mathrm{~S}$ forms (31\%) (Fig. $3 b$ ). Further extraction of the pellet with the non-ionic detergent Triton X-100 plus $1 \mathrm{~m} \mathrm{NaCl}$ and $20 \mathrm{~mm}$ EDTA released most of the $10 \mathrm{~S}$ form $(87 \%)$ and the remainder $(67 \%)$ of the 4 to $6 \mathrm{~S}$ form (Fig. $3 \mathrm{c}$ ). The detergent released no additional $16 \mathrm{~S}$ AChE activity.

These results indicate that the asymmetric, fast sedimenting AChE form $\mathrm{A}_{12}(16 \mathrm{~S})$ is not an integral membrane protein since it can be solubilized without detergent, whereas the $\mathrm{G}_{4} \mathrm{AChE}$ form (10 S), which requires detergent for extraction, presumably is an integral membrane protein. We cannot exclude the alternative possibility that $10 \mathrm{~S} \mathrm{AChE}$ is a peripheral protein attached to an integral membrane protein in some special manner. A significant amount of the $\mathrm{G}_{1}$ and $\mathrm{G}_{2}$ forms (4 to $6 \mathrm{~S}$ ) behaves like a membrane-bound enzyme, but at least $30 \%$ of these forms remains soluble or loosely bound to intracellular elements.

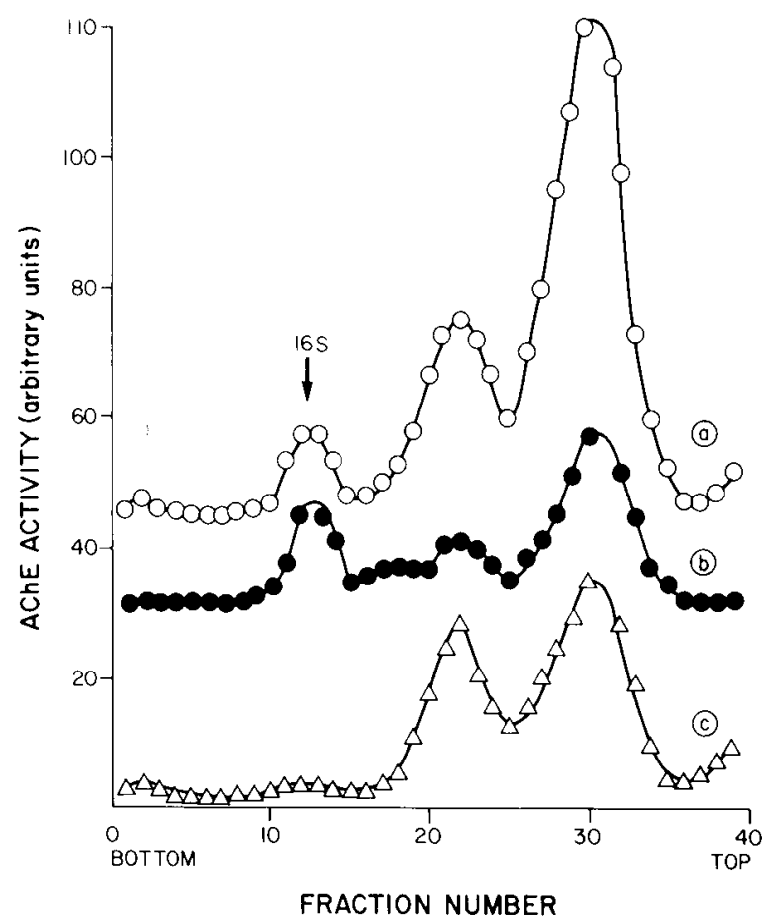

Figure 3. Differential solubilization of AChE forms by high salt concentration. $a$, Sucrose gradient profile of AChE obtained from PC12 cells grown for $5 \mathrm{~d}$ in $2.5 \mathrm{~S} \mathrm{NGF}$, harvested, extracted, and analyzed as in Figure 1. $b$, Sucrose gradient profile of AChE forms from cells grown in $2.5 \mathrm{~S} \mathrm{NGF}$ for $5 \mathrm{~d}$ and extracted in buffer A without detergent. $c$, Sucrose gradient profile of AChE forms extracted in buffer A from the pellet remaining after the high salt extraction and centrifugation shown in $b$.
$16 S$ AChE appears to have a collagen-like tail. Because collagenase removes the AChE from muscle endplates (Hall and Kelly, 1971; Inestrosa et al., 1977), we studied the effect of purified collagenase on the AChE of intact PC12 cells treated with NGF. At $37^{\circ} \mathrm{C}, \mathrm{PC} 12$ cells normally released $\mathrm{AChE}$ into the culture medium. Incubation of the cells with collagenase at $37^{\circ} \mathrm{C}$ caused a small increase in AChE release as shown in Figure $4 a$. Analysis by sucrose gradient sedimentation of the AChE activity of cells treated with collagenase showed that enzyme treatment caused a specific decrease in the $16 \mathrm{~S}$ form associated with the cells. Figure $4 b$ illustrates the $16 \mathrm{~S}$ portion of gradients treated with collagenase for various times. When $\mathrm{PC} 12$ cells were incubated with collagenase for $4 \mathrm{hr}$ at $37^{\circ} \mathrm{C}$, at least $90 \%$ of the $16 \mathrm{~S}$ form was removed from the cells (Fig. $4 \mathrm{c}$ ), although this treatment affected none of the globular forms of $\mathrm{AChE}$. When the activity released into the medium by collagenase was examined on sucrose gradients, it was found to sediment at $10 \mathrm{~S}$ (data not shown). In the absence of collagenase, the cells release primarily $10 \mathrm{~S} \mathrm{AChE}$ with some 4 to $6 \mathrm{~S}$ as originally reported by Rieger et al. (1980b).

Because the collagenous tail of AChE from muscle and electric organ causes the enzyme to be insoluble in low ionic strength buffers (Massoulie, 1980), we tested the effect of low ionic strength on the neuronal forms of the enzyme. An extract of the NGF-treated PC12 cells made with $1 \mathrm{M} \mathrm{NaCl}$ and $0.5 \%$ Triton X-100 was dialyzed against a low salt buffer with detergent. The material thus precipitated was collected by centrifugation and redissolved in high salt plus detergent. Both the supernatant after dialysis and the redissolved pellet were analyzed on sucrose gradients. Figure 5 shows that the 16 $\mathrm{S}$ form is readily separable from the 4 to 6 and $10 \mathrm{~S}$ forms. Under these conditions, only the $\mathrm{A}_{12}$ form (16 $\mathrm{S}$ ) was detected in the low salt-insoluble fraction (Fig. $5 b$ ); we did not find any evidence for asymmetric $A_{8}$ or $A_{4}$ forms in these cells.

On the basis of collagenase sensitivity and low salt insolubility, we conclude that the $16 \mathrm{~S} \mathrm{AChE}$ induced by NGF is an asymmetric form containing a collagen-like domain. The sensitivity of this form to collagenase treatment of intact cells provides further evidence that the 16 $\mathrm{S} A \mathrm{ACh}$ is on the cell surface, where it is accessible to the enzyme.

\section{Discussion}

From our experiments (see Fig. 2 and Table I), it is clear that most $(75 \%)$ of the AChE in NGF-treated rat pheochromocytoma PC12 cells is intracellular and that at least $90 \%$ of this enzyme is comprised of AChE forms with a sedimentation coefficient of 4 to $6 \mathrm{~S}\left(\mathrm{G}_{1}\right.$ and $\mathrm{G}_{2}$ globular forms). These forms behave mostly (56\%) as if they were membrane-bound proteins (Fig. 3) although it is possible that some of these $\mathrm{AChE}$ molecules are soluble but localized within intracellular membranous structures not disrupted by our homogenization procedure. It has been shown recently by histochemical methods that most intracellular AChE activity is localized in cisternae of the rough endoplasmic reticulum, both in NGF-treated and untreated PC12 cells (Lucas et al., 1980). AChE appears 

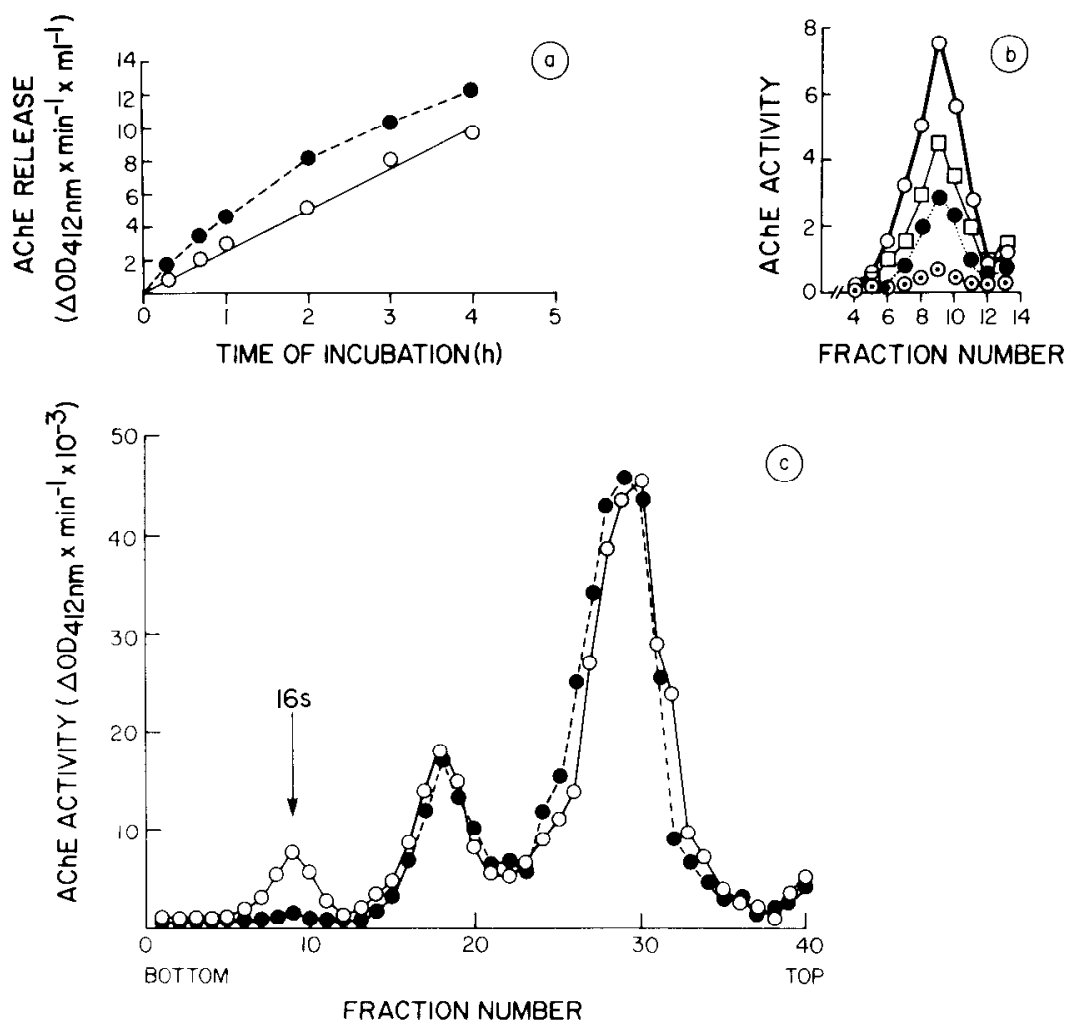

Figure 4. Effect of collagenase on $16 \mathrm{~S} \mathrm{AChE.} a$, Rate of release of total AChE by collagenase. PC12 cells were grown for $5 \mathrm{~d}$ in $100 \mathrm{ng} / \mathrm{ml}$ of $2.5 \mathrm{~S}$ NGF, washed to remove serum, and then incubated in the presence of 0.1 $\mathrm{ng} / \mathrm{ml}$ of collagenase in $20 \mathrm{~mm}$ Tris- $\mathrm{Cl}, \mathrm{pH} 7.4$, and $10 \mathrm{~mm} \mathrm{CaCl}_{2}$ for $4 \mathrm{hr}$. Incubations were at $37^{\circ} \mathrm{C}$ without collagenase $(\mathrm{O})$ and $37^{\circ} \mathrm{C}$ in the presence of collagenase (O). $b$, Selected part of the sucrose gradient showing the 16 $S$ AChE region. An analysis of $\mathrm{AChE}$ forms in collagenase-treated $\mathrm{PC} 12$ cells by sucrose gradient centrifugation is shown. Incubations were at $37^{\circ} \mathrm{C}$ without collagenase $(\bigcirc)$ and $37^{\circ} \mathrm{C}$ for $30 \mathrm{~min}(\square), 70 \mathrm{~min}(\odot)$, or $4 \mathrm{hr}(\odot)$ in the presence of collagenase. $c$, Sucrose gradient profile of AChE forms obtained from PC12 cells grown for $5 \mathrm{~d}$ in $2.5 \mathrm{~S} \mathrm{NGF}$ and then incubated at $37^{\circ} \mathrm{C}$ for $4 \mathrm{hr}$ in the absence $(O)$ or presence $(O)$ of collagenase. Multiplication by 0.0735 converts the results to micromoles of substrate hydrolyzed per min.

to be similarly localized in adrenal chromaffin cells (Somogyi et al., 1975), in neurons of the central nervous system (Kreutzberg and Toth, 1974), and in muscle cells (Sawyer et al., 1976). Our studies of PC12 cells indicate that this activity is likely to correspond to the $G_{1}$ and $G_{2}$ forms; the cisternal localization may reflect the site of synthesis.

Our experiments further indicate that about $25 \%$ of the total AChE in NGF-treated cells is localized on the cell surface or attached to the substratum. Most of this AChE activity corresponds to the $10 \mathrm{~S}$ form, which behaves as an integral membrane protein whose active site is exposed to the medium. Cell surface AChE has been observed also in the adrenal medulla, where some of the AChE is extracellular and appears to be a component of the plasma membrane (Somogyi et al., 1975). In a variety of cell types, $10 \mathrm{~S} \mathrm{AChE}\left(\mathrm{G}_{4}\right)$ has been found to be associated with membranes. Detergent is necesssary for complete solubilization of this form from rat brain (Rieger and Vigny, 1976) and from neuroblastoma cells (Rieger et al., 1976h). Further, in rat neuroblastoma $\times$ sympathetic hybrids (T28) (Rieger et al., 1976a; Lazar and
Vigny, 1980) and in cultured chick muscle (Rotundo and Fambrough, 1980), some of the $\mathrm{G}_{4}$ form is located on the external membrane. Thus, the $10 \mathrm{~S}$ form of PC12 seems to share several properties with the analogous form from other tissues. We observed that $10 \%$ of the $\mathrm{G}_{1}$ and $\mathrm{G}_{2}$ forms was protected by BW, suggesting that this also may be located on the cell surface. This is consistent with the finding of other investigators, who recently reported that some of the $\mathrm{G}_{2}$ form is located on the cell surface (Rotundo and Fambrough, 1980; Taylor et al., 1981).

The rest of the extracellular AChE is the asymmetric $16 \mathrm{~S}$ form which accounts for 4 to $6 \%$ of the total $\mathrm{AChE}$ activity in NGF-treated PC12 cells (Table I). About $10 \%$ of the $16 \mathrm{~S} \mathrm{AChE}$ is resistant to digestion with collagenase (Fig. 4c), raising the possibility that this fraction may have an intracellular location. All of the $16 \mathrm{~S}$ form was protected by $\mathrm{BW}$ from DFP inactivation. Because longer times of pretreatment with BW gave increasing protection of 10 and 4 to $6 \mathrm{~S}$ forms (see the legend to Fig. 2), it is likely that some BW crosses the membrane and pro- 


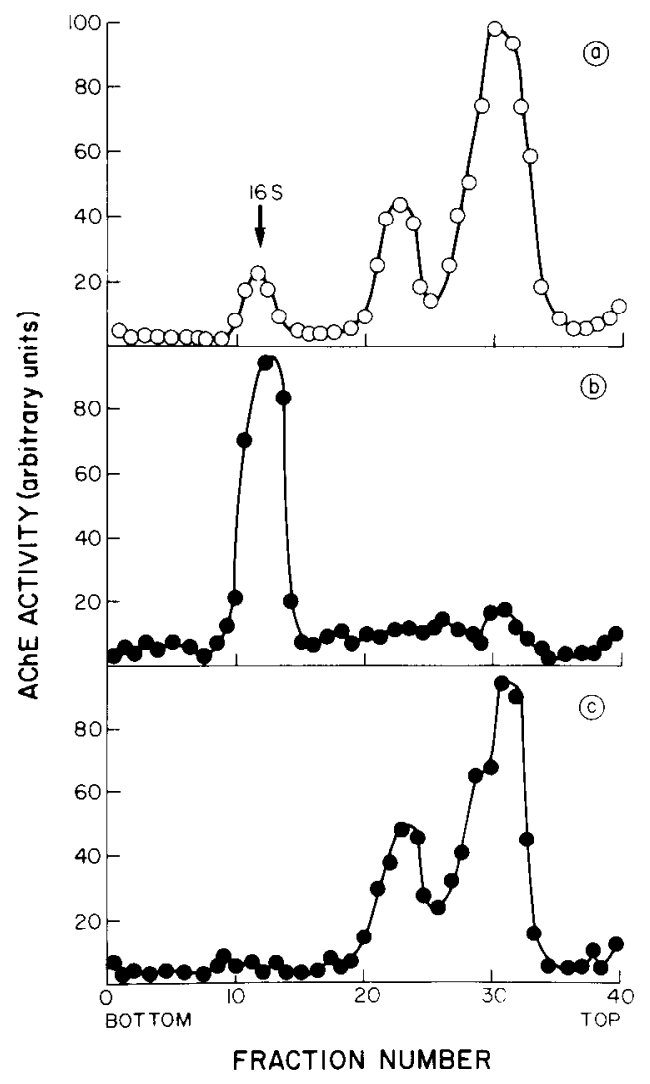

Figure 5. Aggregation of $16 \mathrm{~S} \mathrm{AChE} \mathrm{in} \mathrm{low} \mathrm{salt} \mathrm{buffer.} \mathrm{These}$ gradients were run in a SW 41 Ti rotor at $40,000 \mathrm{rpm}$ for $21 \mathrm{hr}$. For experimental details, see "Materials and Methods." $a$, Molecular forms of $\mathrm{AChE}$ in the original sample prior to dialysis showing the 16, 10, and 4 to $6 \mathrm{~S}$ peaks. $b$, Gradient of material redissolved from the precipitated protein pellet containing only the $16 \mathrm{~S}$ AChE. $c$, Gradient showing the forms remaining in the supernatant following dialysis, 10 and 4 to $6 \mathrm{~S}$. The peak of maximum activity in each figure was assigned a value of 100 and the other points were normalized accordingly.

tects internal AChE. It is thus possible that there is a small internal pool of $16 \mathrm{~S}$ AChE which could have escaped detection in the $\mathrm{BW}$ protection experiments; nevertheless, our results indicate that at least $90 \%$ of the $16 \mathrm{~S} \mathrm{AChE}$ in PC12 cells has an extracellular location.

The precise extracellular location of the $16 \mathrm{~S}$ form is unknown. It is released from its attachment site by high ionic strength, suggesting that it is part of the extracellular matrix. 'The solubilization properties of the enzyme, its sensitivity to collagenase, and its aggregation at low ionic strength suggest that it is analogous to the asymmetric tailed form of AChE that is associated with muscle end-plates (Hall, 1973; Massoulie, 1980). PC12 cells have been reported to form functional contacts with each other (Schubert et al., 1977), and AChE is localized at synaptic regions between splanchnic nerves and adrenal chromaffin cells (Somogyi et al., 1975) from which pheochromocytoma cells are derived. Therefore, it is possible that the $16 \mathrm{~S} \mathrm{AChE}$ in PC12 cells has a synaptic location.

It is not clear whether the neuronal $16 \mathrm{~S} \mathrm{AChE} \mathrm{is}$ associated with a basal lamina, with synaptic cleft material, or with some other form of extracellular matrix. In muscle, at least part of the AChE at the neuromuscular
TABLE I

Cellular localization of AChE molecular forms in NGF-treated PC12 cells

The distribution of AChE forms in NGF-treated PC12 cells is shown. Each column indicates the distribution of each of the AChE forms among the various intra- and extracellular compartments calculated from all of our experiments. The final column indicates the percentage of total AChE in each compartment.

\begin{tabular}{lrrrrr} 
& $\begin{array}{c}\text { Percentage of AChE } \\
\text { Molecular Forms in } \\
\text { Each Compartment }\end{array}$ & $\begin{array}{c}\text { Percentage of Total } \\
\text { Cellular AChE }\end{array}$ \\
\cline { 2 - 4 } & $4-6 \mathrm{~S}$ & $10 \mathrm{~S}$ & $16 \mathrm{~S}$ & \\
\hline $\begin{array}{l}\text { Intracellular } \\
\quad \text { Membrane bound }\end{array}$ & 56 & 27 & $0^{a}$ & 51 \\
$\quad$ Soluble & 33 & $7^{b}$ & $11^{a}$ & $\frac{24}{75} \%$ intracellular \\
& & & & $75 \%$ \\
$\begin{array}{l}\text { Cell surface } \\
\quad \text { Plasma membrane }\end{array}$ & 11 & 66 & 0 & 20 \\
$\quad$ Extracellular matrix & 0 & 0 & 89 & $\underline{5}$ \\
& & & & $25 \%$ cell surface \\
\hline
\end{tabular}

${ }^{a}$ The distribution of $16 \mathrm{~S}$ in the intracellular compartment is unknown; we have arbitrarily localized all of the activity in the soluble compartment.

${ }^{b}$ This amount of $10 \mathrm{~S}$ enzyme may reflect $\mathrm{AChE}$ in small fragments of membrane not pelleted by the centrifugation at $15,000 \times g$ rather than truly soluble enzyme (see Fig. 3).

" $A$ s indicated in the legend to Figure 2, the membrane may be slightly permeable to BW284c51 under our experimental conditions and thus it may protect a small fraction of internal AChE. Accordingly, the values shown here have been corrected by subtracting $10 \%$ of the activity of each molecular form present at the cell surface. Each value is the mean of four (cell surface) and two (intracellular) different experiments; the variation in each case was less than $10 \%$.

junction is associated with the basal lamina (McMahan et al., 1978). Although neurons in vivo do not have a basal lamina on their surface (Schachner et al., 1978), neuroblastoma cells in culture have been demonstrated to produce several basal lamina glycoproteins (Alitalo et al., 1980), and PC12 cells have been shown recently to secrete a variety of basal lamina components including collagen (Greenberg et al., 1980), a laminin-like protein (McGuire et al., 1978), and glycosaminoglycans (W. D. Matthew and L. F. Reichardt, unpublished results). The nature of the extracellular matrix associated with pheochromocytoma cells in culture and its relation to $16 \mathrm{~S}$ $\mathrm{AChE}$ requires further investigation.

Because all AChE forms in a given animal species appear to be catalytically equivalent (Vigny et al., 1978; Massoulie, 1980), the various forms, differentially localized within the cell, may represent different stages in a sequence of well defined aggregation steps and modifications to the basic subunit as it proceeds from the interior to the exterior of the cell. The study of the synthesis, modification, and transmembrane transport of AChE may yield a better understanding of the mechanisms of localization of proteins to the plasma membrane and extracellular matrix.

Finally, an important question in development, especially at the neuromuscular junction, is which cells manufacture and secrete the specific molecules that comprise the extracellular matrix in the synaptic region. In partic- 
ular, the cell of origin of synaptically localized AChE has not been established. Muscle cells are clearly capable of producing $16 \mathrm{~S} \mathrm{AChE}$ in the absence of nerve under appropriate conditions (Sugiyama, 1977; Koenig and Vigny, 1978; Inestrosa et al., 1981; L. Silberstein, N. C. Inestrosa, and Z. W. Hall, submitted for publication). However, the extracellular localization of $16 \mathrm{~S} \mathrm{AChE}$ demonstrated here in a nerve-like cell line, the axonal flow of this form of the molecule (DiGiamberardino and Couraud, 1978; Fernandez et al., 1980), and the decrease in AChE at the neuromuscular junction after blockade of axonal flow (Fernandez and Inestrosa, 1976) suggest that at least a fraction of the AChE at the neuromuscular junction could be of neuronal origin.

\section{References}

Alitalo, K., M. Kurkinen, A. Vaheri, I. Virtanen, H. Rohde, and R. Timpl (1980) Basal lamina glycoproteins are produced by neuroblastoma cells. Nature 287: 465-466.

Bon, S., M. Vigny, and J. Massoulie (1979) Asymmetric and globular forms of acetylcholinesterase in mammals and birds. Proc. Natl. Acad. Sci. U. S. A. 76: 2546-2550.

Dichter, M. A., A. S. Tishler, and L. A. Greene (1977) Nerve growth factor-induced increase in electrical excitability and acetylcholine sensitivity of a rat pheochromocytoma cell line. Nature 268: 501-504.

DiGiamberardino, L., and J. Y. Couraud (1978) Rapid accumulation of high molecular weight acetylcholinesterase in transected sciatic nerve. Nature 271: 170-172.

Ellman, G. L., K. D. Courtney, V. Andres, Jr., and R. M. Featherstone (1961) A new and rapid colorimetric determination of acetylcholinesterase activity. Biochem. Pharmacol. 1: 89-95.

Fernandez, H. L., and N. C. Inestrosa (1976) Role of axoplasmic transport in neurotrophic regulation of muscle end-plate acetylcholinesterase. Nature 262: 55-56.

Fernandez, H. L., M. J. Duell, and B. W. Festoff (1980) Bidirectional axonal transport of $16 \mathrm{~S}$ acetylcholinesterase in rat sciatic nerve. J. Neurobiol. 11: 31-39.

Gisiger, V., M. Vigny, J. Gautron, and F. Rieger (1976) Acetylcholinesterase of rat sympathetic ganglion: Molecular forms, localization and effects of denervation. J. Neurochem. 30: 501-516.

Greenberg, J. H., J. -M. Foidart, and R. M. Greene (1980) Collagen synthesis in cultures of differentiating neural crest cells. Cell Differ. 9: 153-163.

Greene, L. A., and A. S. Tishler (1976) Establishment of a noradrenergic clonal line of rat adrenal pheochromocytoma cells which respond to nerve growth factor. Proc. Natl. Acad. Sci. U. S. A. 73: 2424-2428.

Hall, Z. W. (1973) Multiple forms of acetylcholinesterase and their distribution in endplate and non-endplate regions of rat diaphragm muscle. J. Neurobiol. 4: 343-361.

Hall, Z. W., and R. B. Kelly (1971) Enzymatic detachment of endplate acetylcholinesterase from muscle. Nature New Biol. 232: 62

Inestrosa, N. C., B. U. Ramirez, and H. L. Fernandez (1977) Effect of denervation and of axoplasmic transport blockage on the in vitro release of muscle endplate acetylcholinesterase. J. Neurochem. 28: 941-945.

Inestrosa, N. C., B. Mendez, and J. V. Luco (1979) Acetylcholinesterase like that of skeletal muscle in smooth muscle reinnervated by a motor nerve. Nature 280: 504-506.

Inestrosa, N. C., L. Silberstein, and Z. W. Hall (1981) Appearance of synaptic molecules in aneural myotube cultures. J. Supramol. Struct. Cell. Biochem. Suppl. 5: 297.

Koenig, J., and M. Vigny (1978) Neural induction of the $16 \mathrm{~S}$ acetylcholinesterase in muscle cell cultures. Nature 271:7577.

Kreutzberg, G. W., and L. Toth (1974) Dendritic secretion: A way for the neuron to communicate with the vasculature. Naturwissenschaften $61: 37$.

Lazar, D., and M. Vigny (1980) Modulation of the distribution of acetylcholinesterase molecular forms in a murine neuroblastoma $\times$ sympathetic ganglion cell hybrid cell line. $\mathrm{J}$ Neurochem. 35: 1067-1079.

Lucas, C. A., A. Czlonkowska, and G. W. Kreutzberg (1980) Regulation of acetylcholinesterase by nerve growth factor in the pheochromocytoma PC12 cell line. Neurosci. Lett. 18: 333-337.

Massoulie, J. (1980) The polymorphism of cholinesterases and its physiological significance. Trends Biochem. Sci. 5: 160164.

McGuire, J. C., L. A. Greene, and A. V. Furano (1978) NGF stimulates incorporation of fucose or glucosamine into an external glycoprotein in cultured rat PC12 phcochromocytoma cells. Cell 15: 357-365.

McIssac, R. J., and G. B. Koelle (1959) Comparison of the effects of inhibition of external, internal and total acetylcholinesterase upon ganglionic transmission. J. Pharmacol. Exp. Ther. 126: 9-20.

McMahan, U. J., J. R. Sanes, and L. M. Marshall (1978) Cholinesterase is associated with the basal lamina at the neuromuscular junction. Nature 271: 172-174.

Mobley, W. C., A. Schenker, and E. M. Shooter (1976) Characterization and isolation of proteolytically modified nerve growth factor. Biochemistry 15: 5543-5551.

O'Lague, P. H., and S. L. Huttner (1980) Physiological and morphological studies of rat pheochromocytoma cells (PC12) chemically fused and grown in culture. Proc. Natl. Acad. Sci. U. S. A. 77: 1701-1705.

Rieger, F., and M. Vigny (1976) Solubilization and physicochemical characterization of rat brain acetylcholinesterase: Development and maturation of its molecular forms. J. Neurochem. 27: 121-129.

Rieger, F., P. Taylor, and L. A. Greene (1976a) Cell surface localization of one of the multiple forms of acetylcholinesterase (AChE) in cultured mammalian and avian nerve cells. Soc. Neurosci. Abstr. 2: 612.

Rieger, F., A. Faivre-Bauman, P. Benda, and M. Vigny (1976b) Molecular forms of acetylcholinesterase and their de novo synthesis in mouse neuroblastoma cells. J. Neurochem. 27: 1059-1063.

Rieger, F., R. Chetelat, M. Nicolet, L. Kamal, and M. Poullet (1980a) Presence of tailed asymmetric forms of acetylcholinesterase in the central nervous system of vertebrates. FEBS Lett. 121: 169-174.

Rieger, F., M. L. Shelanski, and L. A. Greene (1980b) The effects of nerve growth factor on acetylcholinesterase and its multiple forms in cultures of rat $\mathrm{PC} 12$ pheochromocytoma cells: Increased total specific activity and appearance of the $16 \mathrm{~S}$ molecular form. Dev. Biol. 76: 238-243.

Rotundo, R. L., and D. M. Fambrough (1980) Synthesis, transport and fate of acetylcholinesterase in cultured chick embryo muscle cells. Cell 22: 583-594.

Rubin, L. L., S. M. Schuetze, C. L. Weill, and G. D. Fischbach (1980) Regulation of acetylcholinesterase appearance at neuromuscular junctions in vitro. Nature 283: 264-267.

Sawyer, H. R., T. K. Golden, P. S. Nieberg, and B. W. Wilson (1976) Ultrastructural localization of acetylcholinesterase in cultured cells. I. Embryo muscle. J. Histochem. Cytochem. 24: 969-978.

Schachner, M., G. Schoonmaker, and R. O. Hynes (1978) Cellular and subcellular localization of LETS protein in the nervous system. Brain Res. 158: 149-158.

Schubert, D., S. Heinemann, and Y. Kidokoro (1977) Cholin- 
ergic metabolism and synapse formation by a rat nerve cell line. Proc. Natl. Acad. Sci. U. S. A. 74: 2579-2583.

Somogyi, P., I. W. Chubb, and A. D. Smith (1975) A possible structural basis for the extracellular release of acetylcholinesterase. Proc. R. Soc. Lond. (Biol.) 191: 271-283.

Sugiyama, H. (1977) Multiple forms of acetylcholinesterase in clonal muscle cells. FEBS Lett. 84: 257-260.

Taylor, P. B., F. Rieger, M. L. Shelanski, and L. A. Greene (1981) Cellular localization of the multiple molecular forms of acetylcholinesterase in cultured neuronal cells. J. Biol. Chem. 256: 3827-3830.

Vigny, M., S. Bon, J. Massoulie, and F. Leterrier (1978) Active site catalytic efficiency of acetylcholinesterase molecular forms in Electrophorus, Torpedo, rat and chicken. Eur. J. Biochem. 85: 317-323.

Weinberg, C. B., and Z. W. Hall (1979) Junctional form of acetylcholinesterase restored at nerve-free endplates. Dev. Biol. 68: 631-635. 